\title{
Construction of Deduction System of Learning Profile from Performance Indicators
}

\author{
Fatima-Zahra Ammor, Driss Bouzidi, and Amina Elomri
}

\begin{abstract}
When leaning, be it a face to face or online, students favor a customized learning that meets their needs and preferences. Learners are more motivated and their evaluation results are satisfactory. Indeed, the adaptation of interventions according to the learning profiles of student is one of the best ways to improve learning. However, a learning profile is easier to detect in a face to face learning situation rather than in an online learning situation, especially when the defining rules the different profiles are imprecise and difficult to formulate in a digital language. In our contribution, we aim to solve this problem by proposing a profile deduction system allowing to translate the performance rules provided by the expert into numerical rules manipulated by the machine, which will facilitate the deduction of learning profiles from interactions made by learners face to training. For this, we will use the algorithm classification ANTClust. An experiment part is proposed to verify the accuracy of the classification performed and the obtained results.
\end{abstract}

Index Terms-E-Learning, deduction system of learning profiles, performance indicators, classification, ANTClust algorithm.

\section{INTRODUCTION}

The e-learning systems aimed to revolutionize the world of training, provide pedagogical training available at any time for all types of people aimed to better support face-to- face training. Unfortunately, this has not been the case and e-learning systems are still experiencing significant dropout rate, which is due to several reasons including the lack of support and sense of isolation that the learner may feel facing the machine. Several solutions have been proposed, ranging from suggestions on working group integration [1] to the analysis of facial expressions to deduce learners emotions [2] [3]. Also, among the proposed solutions and approved for their satisfactory results, we find the adaptation and customization of training by learning profiles of learners. Indeed, learners are more motivated and prepared to advance when provided training is tailored to their needs and preferences. To infer patterns of student learning, there are two ways to do this:

1) Gather information explicitly through questionnaires [4],

[5]. This method gives satisfactory results, but can, on the one hand, bring the learner to be quickly bored. On the other hand, may include risks of disrupting the progress of the learning activity.

Manuscript received November 4, 2012; revised January 8, 2013.

The authors are with the Team: Modeling and Optimization for Mobile Services, Ain Chock Hassan II University- Faculty of Sciences (e-mail: ammor.fatimazahra@gmail.com, d.bouzidi@fsac.ac.ma a.elomri@fsac.ac.ma).
2) Implicit understanding of learner's behavior following his/her interaction with the environment [6], [7]. Recorded traces by the system can be extracted and analyzed to deduce his/her profile. It is this second approach that we have adopted in our work.

However, determining the learning profile of the learner, in an online learning situation, is a difficult task especially when profiling rules are imprecise and difficult to formulate in a digital language and be manipulated by the machine (the learner is stirred in a learning situation, he speaks little, he likes to be alone when working ... etc..). It is therefore necessary to consider a system that transforms the superficial rules defined by the expert teacher in numerical rules facilitating the deduction of learning profiles from learner's interactions face to training. We propose to build a fuzzy system of deduction of learning profiles to:

- Manually gather, by an expert, performance profiling rules defining the different learning profiles.

- Modeling performance rules through behavioral indicators.

- Automatically deduce numerical values representing the characteristics that define the different learning profiles.

- Decide on the learning profile of each student.

Our paper is divided into four main parts. The first part presents some existing learning styles and the tool of the seven profiles that we have adopted. The second part presents the behavior indicators created to facilitate the modeling of profiling rules provided by the expert pedagogue. The third part presents our deduction system of learning profiles (DSLP) based primarily on profiling explicit rules of the expert and profiling implicit rules derived by the classification algorithm ANTClust. The last section presents the experimental results of the algorithm classification and an illustrative example of our system. We conclude our work with a conclusion and perspectives.

\section{LEARNING PROFILES}

Several studies have focused on learning profiles and how to set them. We find for example the learning styles of Kolb [8], the work of Felder and Silverman [9] or the VAK model was used to develop the tool of the seven learning profiles [10]. These works are widely used for the improvement and adaptation of on-learning systems [11]-[14]. Our choice is placed on the tool of seven learning profiles because it allows to:

- Explain the behavior of learners facing a learning situation.

- Guide tutors on the best way to interact with learners and the expressions to use or avoid in order to increase 
their motivation. The very interesting thing to provide personalized accompanying [15].

The seven learning profiles tool consists, among others, of seven identity profiles that define the needs and preferences of an individual in a learning situation and represents the characteristics that each individual possesses and influence on his way of learning. The following Table shows the information that we have for each profile based on three criteria: the level of interest, the time necessary learning and levels of collaboration during learning [10]:

TABLE I: CHARACTERISTICS OF THE SEVEN LEARNING PROFILES IN A FACE

\begin{tabular}{|c|c|c|c|}
\hline $\begin{array}{l}\text { Learning } \\
\text { profile }\end{array}$ & $\begin{array}{c}\text { Level } \\
\text { Of interest }\end{array}$ & $\begin{array}{l}\text { Learning } \\
\text { time }\end{array}$ & $\begin{array}{c}\text { Collaboration } \\
\text { level }\end{array}$ \\
\hline intellectual & $\begin{array}{l}\text { 1) loves to } \\
\text { learn new } \\
\text { things } \\
\text { 2) curious by } \\
\text { nature and } \\
\text { loves to lean } \\
\text { for leaning } \\
\text { sake } \\
\text { 3) involves in } \\
\text { his learnings }\end{array}$ & $\begin{array}{l}\text { 1) takes his } \\
\text { time } \\
\text { 2) needs more } \\
\text { information to } \\
\text { have the feeling } \\
\text { that he } \\
\text { understood the } \\
\text { question }\end{array}$ & $\begin{array}{l}\text { 1) prefers to be } \\
\text { alone while } \\
\text { working } \\
\text { 2) talks a little and } \\
\text { rarely asks } \\
\text { 3) prefers to listen } \\
\text { and analyze } \\
\text { speeches } \\
\text { 4) talkative if the } \\
\text { topic is interesting }\end{array}$ \\
\hline perfectionist & $\begin{array}{l}\text { 1) needs lots } \\
\text { of } \\
\text { information } \\
\text { 2) everything } \\
\text { must be } \\
\text { understood } \\
\text { and well done }\end{array}$ & $\begin{array}{l}\text { 1) dissect the } \\
\text { information to } \\
\text { understand } \\
\text { everything }\end{array}$ & $\begin{array}{lr}1) & \text { honest, } \\
\text { disciplined } & \text { and } \\
\text { pleasant } & \end{array}$ \\
\hline Kind & $\begin{array}{ll}\text { 1) learns to } \\
\text { please } \\
\text { teachers } \\
\text { 2) gives up } \\
\text { when } \\
\text { difficulty }\end{array}$ & $\begin{array}{l}\text { 1) slow learner } \\
\text { compared with } \\
\text { others }\end{array}$ & $\begin{array}{l}\text { 1) kind } \\
\text { 2) pleasant } \\
\text { 3) helpful }\end{array}$ \\
\hline Emotional & $\begin{array}{l}\text { 1) when } \\
\text { depressed his } \\
\text { motivation } \\
\text { goes down } \\
\text { and no longer } \\
\text { learns }\end{array}$ & 1) slow learners & $\begin{array}{l}\text { 1) warm } \\
\text { 2) when not happy } \\
\text { he shows it } \\
\text { 3) unfolds easily }\end{array}$ \\
\hline rebellious & $\begin{array}{l}\text { 1) } \\
\text { conventional } \\
\text { and boring } \\
\text { process .needs } \\
\text { activities to } \\
\text { do things }\end{array}$ & $\begin{array}{l}\text { 1) needs to } \\
\text { expand in his } \\
\text { learning }\end{array}$ & $\begin{array}{l}\text { 1) boisterous } \\
\text { 2) can be verbally } \\
\text { nasty as it can be } \\
\text { extremely nice }\end{array}$ \\
\hline enthusiastic & $\begin{array}{l}\text { 1) learn best if } \\
\text { the subject } \\
\text { gives him } \\
\text { pleasure } \\
\text { 2) being } \\
\text { obliged to } \\
\text { learn under } \\
\text { constraint } \\
\text { increase } \\
\text { demotivation }\end{array}$ & $\begin{array}{l}\text { 1) is struggling } \\
\text { to finish what } \\
\text { he started }\end{array}$ & $\begin{array}{l}\text { 1) is in a good } \\
\text { mood } \\
\text { 2) love the humor } \\
\text { and jokes regularly } \\
\text { 3) quite agitated in } \\
\text { a group situation } \\
\text { 4) nice and very } \\
\text { friendly, } \\
\text { honored is } \\
\text { entertain a group }\end{array}$ \\
\hline Dynamic & $\begin{array}{l}\text { 1) it crashes } \\
\text { when it thinks } \\
\text { it is too } \\
\text { complicated } \\
\text { 2) prefer the } \\
\text { practical side } \\
\text { of things } \\
\text { 3) can be very } \\
\text { average in } \\
\text { learning } \\
\text { situation but } \\
\text { be very good } \\
\text { to get along in } \\
\text { life }\end{array}$ & $\begin{array}{l}\text { 1) Loves have } \\
\text { multiple } \\
\text { activities at the } \\
\text { same time }\end{array}$ & $\begin{array}{l}\text { 1) like to show his } \\
\text { success and } \\
\text { highlight } \\
\text { 2) like to } \\
\text { talk, which is a } \\
\text { problem in } \\
\text { learning situations } \\
\text { 3) has easy contact } \\
\text { with other }\end{array}$ \\
\hline
\end{tabular}

In order to model the characteristics of learning profiles in e-learning context, it is necessary to create behavioral indicators to represent the criteria presented in the Table above.

\section{BEHAVIORAL INDICATORS}

In order to deduce the learners' learning profiles, and after studying the seven learning profiles tool [10], we created three behavioral indicators from the analysis of the behavior of learners:

\section{A. Concentration Rate}

The concentration ratio represents the level of interest of students in relation to the subjects studied, it is calculated by the study of semantic similarity between the courses and the web pages visited during the learner web surfing [16], [17].

$$
R_{\text {Concentration }}=\frac{\sum_{\mathrm{i}=1}^{\mathrm{n}} \operatorname{SimSem}\left(\mathrm{C}, \mathrm{P}_{\mathrm{i}}\right)}{\mathrm{n}}
$$

With:

$n$ represents the number of pages visited during the course learning $C$.

$\operatorname{SimSem}\left(C, P_{i}\right)$ represents the semantic similarity between the current study and the page i visited. It is calculated using the following formula [18]:

$$
\operatorname{SimSem}(C, P)=\sum_{j=1}^{m} \frac{\sum_{i=1}^{l} C_{i} * P_{j} * \operatorname{sim}(i, j)}{\sum_{i=1}^{l} C_{i} * P_{j}}
$$

With:

$i$ represents the concept of the course being studied $j$ represents the concept of the visited page

$q_{i}$ the weight of concept $i$ in the course $d_{j}$ the weight of concept $\mathrm{j}$ in the visited page

And $\operatorname{sim}(i, j)$ represents the semantic similarity between two concepts $i$ and $j$ calculated by measuring edge counting [19]. It is a measure that calculates the semantic similarity based on the number of edges between the two concepts $i$ and $j$ in the shortest path in the hierarchy. Two concepts are more remote, the less they are similar:

$$
\operatorname{Sim}(i, j)=\frac{1}{1+\operatorname{dist}(i, j)}
$$

So if $R_{\text {Concentration }} \approx 0(\approx 1)$, this means that the learner has zero (high) concentration.

\section{B. Collaboration Rate}

Collaboration rate is used to analyze the behavior of the learner in a group situation [20], [21]. We consider that the collaboration rate is equal to the percentage of student participation in working groups. Thus, a learner is considered preferring the collaborative situations when he participates often in working groups.

$$
R_{\text {Collaboration }}=\frac{\sum_{i=1}^{n} \text { number of participation }\left(G_{i}\right)}{\text { total number of participation in } G_{\mathrm{i}}}
$$

With:

number of participation $\left(G_{i}\right)$ represents the number of learner participation in the discussion group $G_{i}$ 
total number of participation in $G_{i}$ represents the total participation of all learners in the group discussion $G_{i}$

So if $R_{\text {Collborati on }} \approx 0(\approx 1)$, this means that the learner prefers not to discuss (prefers to collabore) in a learning situation.

\section{Perseverance Rate}

Perseverance is the time taken for the learner's learning (including study of current course, discussions in the working groups, the consultation pages related to the course, ... etc..) on the total time that learner spent on the platform. So:

$$
R_{\text {Perseverance }}=\frac{T_{C C}}{T_{T A}}
$$

With:

$T_{C C}=$ time during consultation

$T_{T A}=$ total learning time

If $R_{\text {Persévérance }} \approx 0(\approx 1)$, this means that the learner has a zero (high) perseverance.

\section{DEDUCTION SYSTEM OF LEARNING PROFILES (DSLP)}

Our system DSLP allows exploiting explicitly the provided knowledge by expert teachers - knowledge to giving an overview on the different profiles - to build profiling rules understandable by the machine, and to decide on the learners' learning profiles. DSLP is presented as follows:

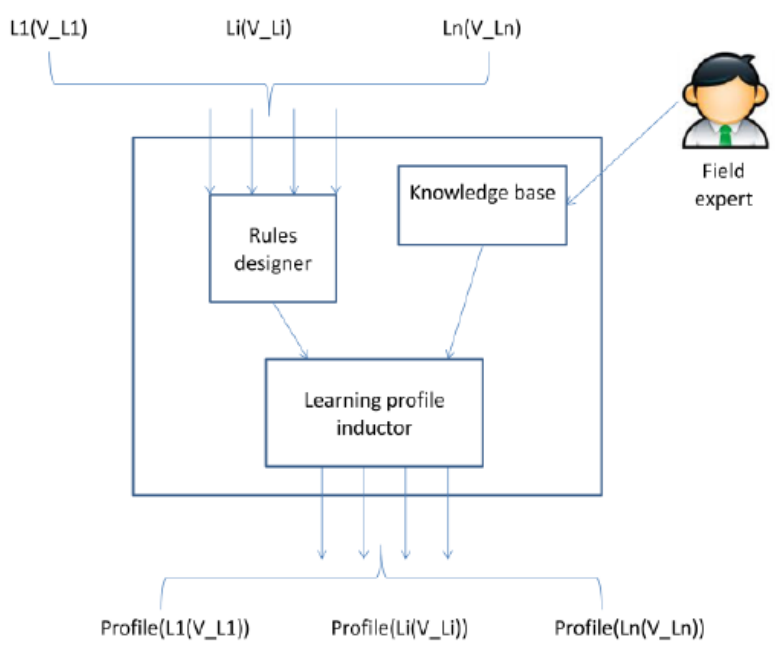

Fig. 1. Deduction system of learning profile.

The system retrieves in input learners' behavioral vectors defined by three indicators seen a bit above - to give as output their learning profiles. Thus, each student is represented by the vector $L_{i}\left(R_{\text {Concentration } i}, R_{\text {Collaboration } i}, R_{\text {Perseverance } i}\right)$ $/ i=\{1, \ldots, \mathrm{p}\}$ where $\mathrm{p}$ is the number of learners enrolled in the learning platform.

Our system consists of three main components:

\section{A. Knowledge Base}

Knowledge Base gathers information collected from the work of Michel [10] according to behavioral indicators. This is a job that requires collaboration between a teacher and a computer expert. The following figure shows the resulting rules:

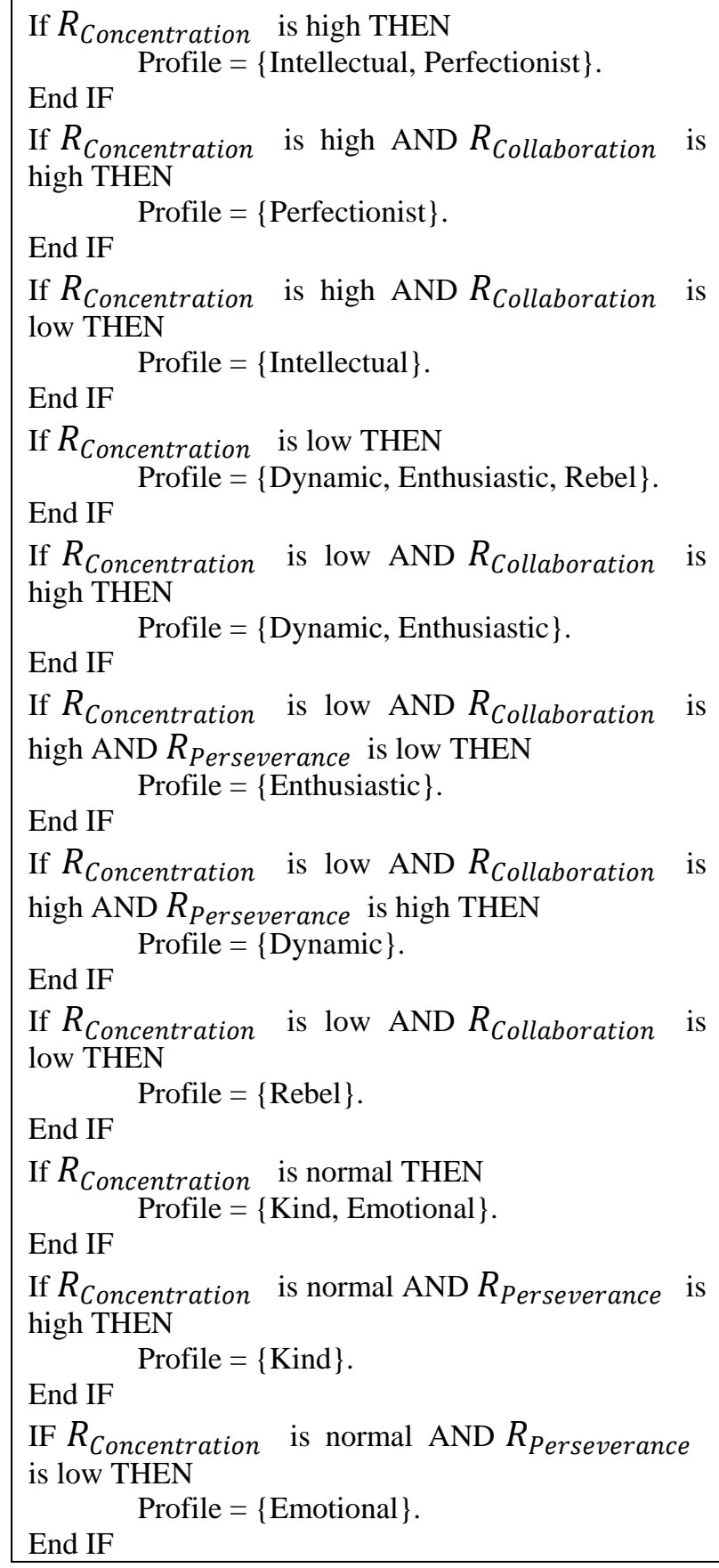

Fig. 2. Profiling rules established through the study of the seven learning profiles.

\section{B. Rules Designer}

Rules designer applies clustering method to create rules equivalent to the rules defined in the knowledge base, and then use these rules to infer learning profiles. This module allows to create seven rules based on numeric values representing the seven learning profiles, and this is thanks to the ANTClust algorithm of classification (Fig. 3). Indeed, it allows classifying learners into groups according to their similarities and then associating each created group with the profile it represents the better [22]-[24]. Classification algorithms have been widely used in order to deduce learners' learning profiles [25]-[27].

The choice of algorithm ANTClust [28], [29] was random when it responds to two major problems:

1) The algorithm used allows to classify a large number of learners 
2) ANTClust is a non supervised clustering algorithm, it is not necessary to specify the group number. In fact, we used a clustering algorithm in order to ensure the appropriateness of selected indicators.

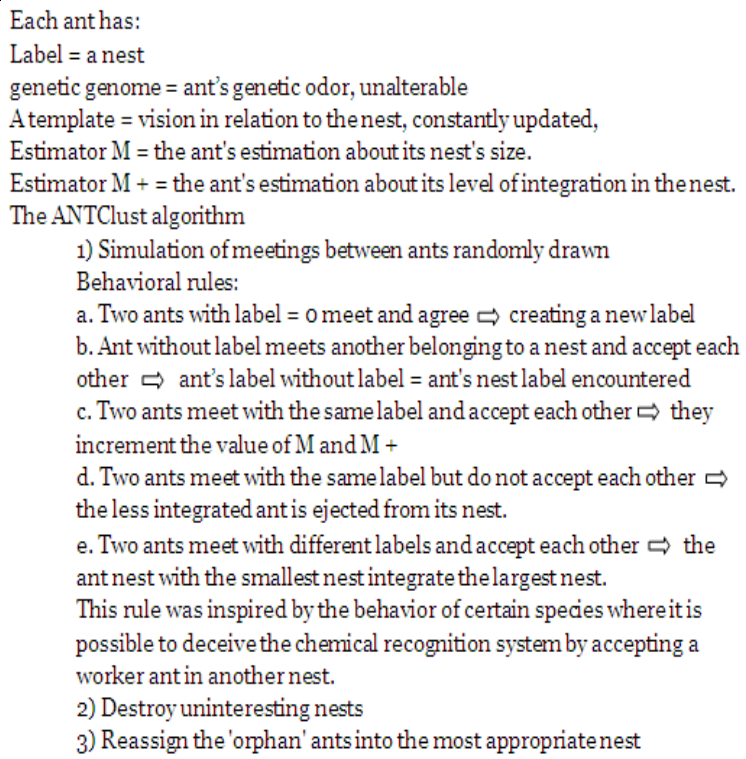

Fig. 3. The ANTClust algorithm of classification.

\section{Learning Profiles Inductor}

The inductor profiles can exploit profiling rules explicitly presented by experts and rules implicitly defined by the classification algorithm to decide on student learning profiles. Thus, the two groups created with the highest values of $R_{\text {Concentration }}$ represent the perfectionist's learners and the intellectual's learners, and the intellectual's learners are one of two groups with low $R_{\text {Collaboration }}$. And with the same logic the other profiles are derived ... etc.

\section{EXPERIMENTATION}

To ensure the relevance of the classification algorithm ANTClust and indicators chosen for classification, we have tested the algorithm in a database containing 1000 learners. The following Table shows the obtained results using behavioral indicators chosen:

TABLE II: THE RESULTS OF CLASSIFICATION

\begin{tabular}{|l|c|c|c|c|c|c|c|}
\hline \multirow{2}{*}{} & \multicolumn{8}{|c|}{ Created groups } \\
\cline { 2 - 8 } & $G_{1}$ & $G_{2}$ & $G_{3}$ & $G_{4}$ & $G_{5}$ & $G_{6}$ & $G_{7}$ \\
\hline ANTClust & 273 & 209 & 166 & 107 & 87 & 68 & 48 \\
\hline
\end{tabular}

The clustering algorithm creates 20 different groups, 958 of them are grouped into the busiest seven groups, others are scattered in 13 other groups. Thus, the algorithm classifies ANTClust learners through behavioral indicators with a rate of misclassification equal to $4.2 \%$.

In the classification, we note that much of students gathered in the seven main groups, others contain less than 10 learners. This confirms the validity of our choice of three behavioral indicators. To better understand the steps of deduction system of learning profiles (DSLP), we present an illustrative example.

After each learner is connected to the e-learning platform and to make his first learning stage. Our system DSLP calculates behavior indicators of each learner and constructs the behavioral vector. The following Table shows the initial information of DSLP:

TABLE III: INITIAL INFORMATION OF DSLP

\begin{tabular}{|c|l|l|l|l|}
\hline Learner & $\mathrm{R}_{\text {Con }_{j}}$ & $\mathrm{R}_{\text {Collab }_{j}}$ & $\mathrm{R}_{\text {Pers }_{j}}$ & Profile \\
\hline $\mathrm{L}_{1}$ & 0.443 & 0.395 & 0.690 & Nul \\
\hline $\mathrm{L}_{2}$ & 0.873 & 0.427 & 0.351 & Nul \\
\hline$\ldots$ & & & & \\
\hline $\mathrm{L}_{500}$ & 0.323 & 0.087 & 0.561 & Nul \\
\hline$\ldots$ & & & & \\
\hline $\mathrm{L}_{1000}$ & 0.613 & 0.348 & 0.343 & Nul \\
\hline
\end{tabular}

These data are then presented to the rules designer to classify learners according to their similarities and create seven groups representing the seven learning profiles (Table III):

TABLE IV: RULES DESIGNER RESULTS

\begin{tabular}{|c|c|l|l|c|}
\hline Group & $R_{\text {Con }_{j}}$ & $R_{\text {Collab }_{j}}$ & $R_{\text {Pers }_{j}}$ & Number of learners \\
\hline$G_{1}$ & 0.079 & 0.149 & 0.152 & 273 \\
\hline$G_{2}$ & 0.186 & 0.155 & 0.052 & 209 \\
\hline$G_{3}$ & 0.089 & 0.049 & 0.219 & 166 \\
\hline$G_{4}$ & 0.181 & 0.042 & 0.127 & 107 \\
\hline$G_{5}$ & 0.136 & 0.187 & 0.078 & 87 \\
\hline$G_{6}$ & 0.112 & 0.121 & 0.136 & 68 \\
\hline$G_{7}$ & 0.103 & 0.265 & 0.078 & 48 \\
\hline
\end{tabular}

Not to be output without learners profile, we combined the 13 other groups of learners in a $G_{i} / i=\{1 . .7\}$ the most suitable.

After each learner is associated with one of seven groups established, the learning profiles inductor retrieves profiling rules defined in the knowledge base (Fig. 2) and the results of the rules designer to associate each group to profile that represents it the best (Table V, Table VI, Table VII).

TABLE V: Associating Groups to the Best LEARNing Profile ACCORDING TO THE VALUE OF $R_{\text {Concentration }}$

\begin{tabular}{|c|c|c|}
\hline Group & $R_{\text {Con }_{i}}$ & Profile \\
\hline$G_{1}$ & 0.079 & Dynamic, Enthusiastic, Rebel \\
\hline$G_{2}$ & 0.186 & Intellectual, Perfectionist \\
\hline$G_{3}$ & 0.089 & Dynamic, Enthusiastic, Rebel \\
\hline$G_{4}$ & 0.181 & Intellectual, Perfectionist \\
\hline$G_{5}$ & 0.136 & Kind, Emotional \\
\hline$G_{6}$ & 0.112 & Kind, Emotional \\
\hline$G_{7}$ & 0.103 & Dynamic, Enthusiastic, Rebel \\
\hline
\end{tabular}

TABLE VI: Associating GRoups to the Best LEARNING PROFILE ACCORDING TO THE VALUE OF $R_{\text {Concentration }}$ AND $R_{\text {Collaboration }}$

\begin{tabular}{|c|c|c|c|}
\hline Group & $R_{\text {Con }_{i}}$ & $R_{\text {Collab }_{i}}$ & Profile \\
\hline$G_{1}$ & 0.079 & 0.149 & Dynamic, Enthusiastic \\
\hline$G_{2}$ & 0.186 & 0.155 & Perfectionist \\
\hline$G_{3}$ & 0.089 & 0.049 & Rebel \\
\hline$G_{4}$ & 0.181 & 0.042 & Intellectual \\
\hline$G_{5}$ & 0.136 & 0.187 & Kind, Emotional \\
\hline$G_{6}$ & 0.112 & 0.121 & Kind, Emotional \\
\hline$G_{7}$ & 0.103 & 0.265 & Dynamic, Enthusiastic \\
\hline
\end{tabular}


TABLE VII: ASSOCIATING GRouPS TO THE BEST LEARNING PROFILE ACCORDING TO THE VALUE OF

$R_{\text {Concentration }}$ AND $R_{\text {Collaboration }}$ AND $R_{\text {Perseverance }}$

\begin{tabular}{|c|c|c|c|c|}
\hline Group & $R_{\text {Con }_{j}}$ & $R_{\text {Collab }_{j}}$ & $R_{\text {Pers }_{j}}$ & Profile \\
\hline$G_{1}$ & 0.079 & 0.149 & 0.152 & Dynamic \\
\hline$G_{2}$ & 0.186 & 0.155 & 0.052 & Perfectionist \\
\hline$G_{3}$ & 0.089 & 0.049 & 0.219 & Rebel \\
\hline$G_{4}$ & 0.181 & 0.042 & 0.127 & Intellectual \\
\hline$G_{5}$ & 0.136 & 0.187 & 0.078 & Emotional \\
\hline$G_{6}$ & 0.112 & 0.121 & 0.136 & Kind \\
\hline$G_{7}$ & 0.103 & 0.265 & 0.078 & Enthusiastic \\
\hline
\end{tabular}

Consequently, DSLP system presents as output the learning profile of each learner (Table V):

TABLE VIII: NUMBER OF LEARNERS IN EACH LEARNING PROFILE
\begin{tabular}{|c|c|c|}
\hline Group & Profile & Number of learners/group \\
\hline$G_{1}$ & Dynamic & 278 \\
\hline$G_{2}$ & Perfectionist & 209 \\
\hline$G_{3}$ & Rebel & 166 \\
\hline$G_{4}$ & Intellectual & 119 \\
\hline$G_{5}$ & Emotional & 89 \\
\hline$G_{6}$ & Kind & 88 \\
\hline$G_{7}$ & Enthusiastic & 51 \\
\hline
\end{tabular}

\section{CONCLUSiOn ANd PeRsPeCtives}

The e-learning systems increasingly interests researchers saw their ambitions to best support face-to- face learning. Unfortunately, this has not been realized and e-Learning systems are still experiencing significant dropout rate. In our paper, we propose a deduction system of learning profiles (DSLP) to analyze the behavior of learners facing training in order to infer their learning profiles. However, this deduction is not easy to achieve because the rules defining the different profiles cannot be modeled with numerical values and thus difficult to handle by the machine. We propose, to solve this problem, to create behavioral indicators representing the criteria for the different profiles and to use them to classify the learners according to their similarities and associate each group created with profile that represents it the best using a knowledge filled by experts. The classification is achieved through the classification algorithm ANTClust that helped us to validate our choice of behavioral indicators and to deduce learners' learning profiles. We see as next work to improve the classification algorithm used to reduce the rate of misclassification found.

\section{REFERENCES}

[1] E. Blanchard and C. Frasson, "Une architecture multi-agents pour des sessions d'apprentissage collaboratif," Technologies de l'Information et de la Communication dans les Enseignements d'ingénieurs et dans l'industrie, Villeurbanne : France, 2002.

[2] R. Nkambou and V. Heritier, "Reconnaissance émotionnelle par l'analyse des expressions faciales dans un tuteur intelligent affectif," Technologies de l'Information et de la Connaissance dans l'Enseignement Supérieur et l'Industrie, Compiègne : France, 2004.

[3] C. Shan, S. Gong, and P. McOwan, "Beyond facial expressions: Learning human emotion from body gestures," in Proc. British Machine Vision Conference on Warwick, UK, September 2007.

[4] A. ElHassan and E. Elbachiri, "Adaptation du contenu des ressources pédagogiques et des profils des apprenants dans l'e-learning," Journées scientifiques Resatice, Rabat, 2007.

[5] R. Lacurezeanu, V. P. Bresfelean, and R. Buchmann, "Mining the students' preferences regarding e-learning environments," in Proc. the 9th WSEAS international conference on Software engineering, parallel and distributed systems, 2010.
[6] M. B. Sassi and M. Laroussi, "Analyse des traces dans Moodle," in Proc. Conférence on Environnements Informatiques pour l'Apprentissage Humain, 2009.

[7] I. S. W. V. Ruggiero and M. Rosatelli, "An Approach in Personalisation and Privacy in E-Learning Systems," InTech, February 2010.

[8] D. Kolb, Experiential learning: experience as the source of learning and development, N.J, Englewood Cliffs, Toronto, Prentice Hall, 1984.

[9] R. Felder and L. Silverman, "Learning and Teaching Styles in Engineering Education," Engineering Education, 1988, vol. 78, no. 7, pp. 674-681.

[10] J.-F. Michel, "Les sept profils d'apprentissage," Pour former et enseigner, Paris, 2005.

[11] J. Mota. Using Learning Styles and Neural Networks as an Approach to eLearning Content and Layout Adaptation. [Online]. Available: http://paginas.fe.up.pt/ prodei/DSIE08/papers/35.pdf.

[12] A. L. Franzoni and S. Assar, "Student Learning Styles Adaptation Method Based on Teaching Strategies and Electronic Media," Educational Technology and Society, 2009, vol. 12, no. 4, pp. 15-29.

[13] M. P. A. Caron, "Adaptativité générique et itérative d'un EIAH aux styles d'interaction des étudiants," in Proc. Conférence on Environnements Informatiques pour l'Apprentissage Humain, Belgique, 2011.

[14] B. Coulibaly, "Essai de détermination de styles d'apprentissage en apprentissage collaboratif à distance," Colloque JOCAIR'06, Premières Journées Communication et Apprentissage Instrumentés en Réseau, Amiens, 6-7 juillet, 2006.

[15] F. Z. Ammor and D. Bouzidi, "A multi-agent system for a suitable tutoring accompaniement," in Proc. International association for Development of the Information Society, Lisbonne, Portugal, 2012.

[16] M. Khatraoui, N. Bousbia, and B. Amar, "Détection de similarité sémantique entre pages visitées durant une session d'apprentissage," in Proc. Atelier Mesures de Similarité Sémantique, EGC'2008, Journées Francophones sur l'Extraction et Gestion des Connaissances, 2008, pp. 121-129.

[17] H. Z. Ayouna and S. Salotti. "Mesure de similarité dans une ontologie pour l'indexation sémantique de documents XML," in Proc. Actes de la conférence Ingénierie des Connaissances, Mai, 2004.

[18] N. Bousbia, J.-M. Labat, I. Rebai, and A. Balla, "Détermination d'indicateurs pour l'identification des styles d'apprentissage : Cas de l'indicateur de typologie de navigation," Environnements Informatiques pour l'Apprentissage Humain, Le Mans 2009

[19] R. Rada, H. Mili, E. Bicknell, and M. Blettner "Development and application of a metric on semantic nets," IEEE Transaction on Systems, Man and Cybernetics, 1989, vol. 19, no. 1, pp. 17-30

[20] T, A. Mille and M. Benmohammed, SBT-IM: Système à base de traces-Indicateurs d'interactions Moodle, EIAH 2011, Mons.

[21] Modes de collaborations au sein de groupes d'apprentissage dans une formation à distance universitaire, Technologies de l'Information et de la Connaissance dans l'Enseignement Supérieur et l'Industrie, Compiègne : France, 2004

[22] F. Z. Ammor, D. Bouzidi, and A. Elomri, "Use the artificial ants for a classification of learner's profiles with a view to a customized tutoring," International Workshop on Information Technologies and Communication, Casablanca, Morocco, pp. 13-15 October 2011.

[23] F. Z. Ammor, D. Bouzidi, and A. Elomri, "An Automatic and Customized Support Based on Artificial Ants," Colloquium on Information Science and Technology, Fez, Morocco, 2012.

[24] F. Z. Ammor, D. Bouzidi, and A. Elomri, "Evaluation of Behavioral Changes for Deduction the Learning Profiles," presented at 4th International Conference on Next Generation Networks and Services, Algarve-Portugal, December 2012, pp. 2-4.

[25] Y. C. Chang, W. Y. Kao, C. P. Chu, and C. H. Chiu, "A learning style classification mechanism for e-learning," Journal Computers \& Education, Elsevier Science Ltd. Oxford, UK, vol. 53, issue 2, September, 2009, pp. 273-285.

[26] M. Joshi, R. Vaidya, and P. Lingras, "Automatic Determination of Learning Styles," in Proc. 2nd international Conference on Education and Management Technology, IACSIT Press, Singapore, vol. 13, 2011.

[27] E. Özpolat and G. B. Akar, "Automatic detection of learning styles for an e-learning system," Computers \& Education, 2009, vol. 53, pp. 355-367.

[28] N. Labroche, N. Monmarché, and G. Venturini, "Modélisation de la fermeture coloniale chez les fourmis pour la classification non-supervisée," in Proc. Conférence d'apprentissage, pp. 137-148, Orléans, France, 17-19 juin 2002, Presses Universitaires de Grenoble.

[29] N. Labroche, Modélisation du système de reconnaissance chimique des fourmis pour le problème de la classification non-supervisée application à la mesure d'audience sur Internet, PhD thesis, 
Laboratoire d'Informatique de Tours, UPRES EA 2101, 4 décembre 2003, Responsable: Pr. Gilles Venturini.

Fatima-Zahra Ammor was born in Casablanca, Morocco in 1986, she is a $\mathrm{Ph} . \mathrm{D}$ student at the Faculty of Sciences - University Hassan II in Casablanca - Morocco since 2010, specialty Computer Science. She has a Master in the same Faculty specialty Internet and Computer Engineering and she wanted to continue in the same field for her particular interest to the new technology. Her research interests concern particularly the e-learning system.

Driss Bouzidi is an assistance professor in Computer Science at the Faculty of Sciences, University Hassan II Ain Chock, Casablanca, Morocco. He received his $\mathrm{Ph} . \mathrm{D}$. degree in computer engineering from Mohammed V University in 2004. His research focuses especially on Collaboration systems and e-learning. He has participated with many research papers in workshops and conferences, and published in the National and International referred Journals (MJCCSSP, IJCSI, IJACSA). He has contributed chapters in some international books related to e-Learning. He has also participated in a few elearning projects (e-learning Judicial Curriculum, EUMEDIS, etc.).

He was vice-chair of the international conference NGNS'09, and TCP chair of NGNS10 and NGNS12. He is the treasurer of the two research associations e-NGN and APRIMT

Amina Elomri is a professor of Higher Education in Computer Science a the Faculty of Sciences, University Hassan II Ain Chock, Casablanca, Morocco. Her main scientific interests concern the optimization, transport and the logistic problems. She is responsible of a research team in the same faculty entitled "Modeling and Optimization for Mobile Services". She has participated with more than 20 research papers in workshops and conferences and published journal articles. 